\title{
Pengaruh Jenis Kemasan terhadap Daya Simpan Benih Kedelai (Glycine max (L.) Merrill) Varietas Anjasmoro
}

\author{
The Effect of Packaging Material Types on Storage Endurance of Soybean Seed (Glycine max (L.) \\ Merrill) Anjasmoro Varieties
}

\author{
Fadilah Ramadhani, Memen Surahman*, dan Andri Ernawati
}

\author{
Departemen Agronomi dan Hortikultura, Fakultas Pertanian, Institut Pertanian Bogor \\ (Bogor Agricultural University), J1. Meranti, Kampus IPB Darmaga, Bogor 16680, Indonesia \\ Telp. \& Faks.62-251-8629353 e-mail agronipb@indo.net.id \\ *Penulis Korespondensi : memensurahman@yahoo.com
}

Disetujui : 15 Januari 2018 / Published Online 23 Januari 2018

\begin{abstract}
The research aimed to determine the effect on three types of packaging materials namely hermetic packaging, plastic jerigen and plastic layered sacks towards both physical and physiological quality of soybean seed (Glycine max (L.) Merrill) Anjasmoro variety, during storage period. This research was conducted at The Laboratory of Seed Science and Technology, Department of Agronomy and Horticulture, Faculty of Agriculture, Bogor Agriculture University from January to July 2016. Completely Randomize Design (CRD) with three replications was used. The factor of treatment used is the type of packaging materials $(P)$ which consists of three levels: hermetic packaging (P1), plastic jerigen (P2) and plastic layered sacks (P3). The seed was stored for 6 months. The moisture content and seed viability (germination, vigor index, growth speed, dry matter of seedling) was observed monthly seed moisture content. The result showed that types of packaging materials treatment did not influence physical and physiological quality of soybean seed, Anjasmoro variety, during storage period. The treatment of each types of packaging has revealed to sustain both viability and vigor of soy seeds up to the 2 nd month of storage period. Thus, proven that the soy seed is capable of enduring 4 months of storage period after the harvest time.
\end{abstract}

Keywords:hermetic, plastic jerigen, physical and physiological quality, storage.

\section{ABSTRAK}

Penelitian ini bertujuan untuk mengetahui pengaruh tiga jenis kemasan yaitu kemasan hermetik, jeriken plastik dan karung beralas plastik terhadap mutu fisik maupun fisiologis benih kedelai (Glycine max (L.) Merrill) varietas Anjasmoro selama penyimpanan. Penelitian dilaksanakan di Laboratorium Ilmu dan Teknologi Benih, Departemen Agronomi dan Hortikultura, Fakultas Pertanian, Institut Pertanian Bogor pada bulan Januari sampai Juli 2016. Rancangan yang digunakan adalah rancangan acak lengkap (RAL) dengan tiga ulangan. Faktor perlakuan yang digunakan adalah jenis kemasan $(P)$ yang terdiri atas tiga taraf yaitu kemasan hermetik (P1), jeriken plastik (P2), dan karung beralas plastik (P3). Penyimpanan dilakukan selama 6 bulan dan diamati setiap bulan terhadap variabel kadar air, daya berkecambah, indeks vigor, kecepatan tumbuh, keserempakan tumbuh dan bobot kering kecambah normal. Hasil penelitian menunjukkan bahwa perlakuan jenis kemasan tidak memberikan pengaruh yang nyata terhadap mutu fisik maupun fisiologis benih kedelai varietas Anjasmoro selama penyimpanan. Perlakuan jenis kemasan dapat mempertahankan viabilitas dan vigor benih kedelai hingga bulan ke-2 penyimpanan. Hasil tersebut menunjukan bahwa benih kedelai dapat disimpan selama 4 bulan setelah panen.

Kata kunci: hermetik, jeriken plastik, mutu fisik dan fisiologis, penyimpanan. 


\section{PENDAHULUAN}

Kedelai (Glycine $\max$ (L.) Merrill) merupakan komoditas pangan yang terkenal sebagai bahan baku untuk tempe, tahu dan kecap. Kedelai dijadikan sebagai bahan makanan tambahan karena memiliki kandungan protein tinggi. Bungkil kedelai juga dapat dimanfaatkan untuk bahan pakan ternak. Hal tersebut menunjukan bahwa komoditas ini sangat bermanfaat bagi masyarakat Indonesia, maka komoditas ini menjadi salah satu target dalam pencapaian swasembada pangan. Badan Pusat Statistik (2015) menyatakan bahwa produksi kedelai pada tahun 2014 mencapai 953.956 ton dengan luasan panen 615.019 ha, sedangkan pada tahun 2013 produksi kedelai hanya 779.992 ton dengan luasan panen 550.793 ha. Hal ini menunjukkan bahwa perluasan lahan pertanaman kedelai dapat memberikan dampak yang baik untuk meningkatkan produksi kedelai. Selain luas lahan, penggunaan benih bermutu, teknik budidaya, inovasi teknologi dan penangan pasca panen juga diperlukan untuk meningkatkan nilai produktivitas kedelai.

Salah satu faktor yang menentukan keberhasilan pengembangan tanaman kedelai adalah tersedianya benih bermutu dengan daya berkecambah $>80 \%$. Benih bermutu dihasilkan melalui penanganan panen dan pasca panen yang tepat, antara lain penyimpanan (Kartono, 2004). Kedelai merupakan salah satu tanaman palawija yang memiliki kadar protein yang tinggi yaitu $37 \%$. Selain protein, benih kedelai juga mengandung lemak cukup tinggi yaitu $16 \%$. Kandungan protein dan lemak yang tinggi menyebabkan benih kedelai cepat mengalami kemunduran terutama jika kondisi lingkungan simpan kurang menguntungkan (Tatipata et al., 2004). Tujuan utama penyimpanan benih adalah untuk mempertahankan viabilitas benih dalam periode simpan yang sepanjang mungkin (Sadjad, 1977). Penyimpanan juga bertujuan untuk menjaga ketersediaan benih dan untuk mengawetkan cadangan bahan tanam dari satu musim ke musim berikutnya. Semakin berkembangnya pertanian maka penyimpanan benih diarahkan untuk dapat mempertahankan viabilitas benih sepanjang mungkin dengan mengkondisikannya pada penyimpanan yang tepat (Justice dan Bass, 2002).

Benih bermutu mempunyai sifat fisiologis, fisik dan genetik yang baik, yang dipengaruhi oleh proses produksi sampai penyimpanan (Sadjad, 1980). Menurut Purwanti (2004) pengadaan benih kedelai tepat jumlah dan waktu sering terkendala oleh daya simpan benih yang rendah. Penyediaan benih kedelai bermutu di Indonesia saat ini masih mengalami kendala yaitu kemunduran benih kedelai yang berlangsung cepat selama penyimpanan. Kemunduran benih secara cepat tersebut terutama disebabkan oleh tingginya kandungan protein dan kondisi lingkungan tropis dengan kelembapan yang tinggi. Menurut Tatipata et al. (2004) kemunduran benih dapat ditengarai secara biokimia dan fisiologi. Indikasi biokimia kemunduran benih dicirikan antara lain penurunan aktivitas enzim, penurunan cadangan makanan, meningkatnya nilai konduktivitas. Indikasi fisiologi kemunduran benih antara lain penurunan daya berkecambah dan vigor.

Kemunduran benih merupakan proses penurunan mutu secara berangsur-angsur dan kumulatif serta tidak dapat balik (irreversible) akibat perubahan fisiologis yang disebabkan oleh faktor dari dalam benih. Proses penuaan atau mundurnya vigor secara fisiologis ditandai dengan penurunan daya berkecambah, peningkatan jumlah kecambah abnormal, penurunan pemunculan kecambah di lapangan (field emergence), terhambatnya pertumbuhan dan perkembangan tanaman, meningkatnya kepekaan terhadap lingkungan yang ekstrim dan akhirnya dapat menurunkan produksi tanaman (Copeland dan McDonald, 2001). Faktor penyebab penurunan vigor dan daya berkecambah adalah suhu dan kadar air tinggi (Harrington, 1973). Menurut Justice dan Bass (2002) kadar air benih dipengaruhi oleh kelembaban nisbi ruang simpan. Harrington (1972) menyatakan bahwa setiap peningkatan kadar air sebesar 1\% (pada kisaran 514\%) akan menurunkan daya simpan benih setengahnya.

Benih yang dikemas dalam kemasan yang kurang baik akan mengalami penurunan daya tumbuh sehingga diperlukan kemasan yang sesuai bagi benih dalam penyimpanan. Fungsi kemasan dalam penyimpanan benih adalah melindungi kualitas fisik maupun fisiologis benih dari pengaruh lingkungan simpan, menghindari tercecernya benih dan memudahkan dalam distribusi. Bahan, metode dan alat pengemas ditentukan oleh jenis dan jumlah benih, tipe kemasan, lama penyimpanan, suhu penyimpanan, kelembaban areal penyimpanan, pendistribusian benih dan transportasinya (Justice dan Bass, 2002). Metode pengemasan yang tertutup dapat mengisolasi benih yang disimpan dari pengaruh kondisi di luar wadah simpan, terutama bila terjadi fluktuasi kelembaban (Owen, 1956). Efektivitas kemasan ditentukan oleh kemampuan kemasan dalam mempertahankan kadar air dan viabilitas benih. Benih bersifat higroskopik dan 
kadar airnya selalu berkeseimbangan dengan kelembaban nisbi sekitarnya (Copeland, 1976).

Benih kedelai yang digunakan dalam penelitian ini adalah benih kedelai varietas Anjasmoro. Varietas tersebut merupakan salah satu varietas unggul kedelai di Indonesia. Benih verietas Anjasmoro memiliki ukuran benih yang tergolong besar, diukur dari bobot 100 butir benihnya yaitu 14.8-15.3 gram per 100 butir. Perbedaan ukuran benih diduga mempengaruhi perbedaan kandungan kadar air pada benih. Penyimpanan benih kedelai dalam penelitian ini menggunakan tiga jenis kemasan yaitu kemasan hermetik, jeriken plastik dan karung beralas plastik dengan ruang simpan yang sama untuk mengetahui pengaruhnya terhadap mutu fisik dan fisiologis benih tersebut.

\section{METODE PENELITIAN}

Penelitian ini dilaksanakan di Laboratorium Ilmu dan Teknologi Benih, Departemen Agronomi dan Hortikultura, Fakultas Pertanian, Institut Pertanian Bogor pada bulan Januari sampai bulan Juli 2016. Bahan-bahan yang digunakan meliputi benih kedelai varietas Anjasmoro, kertas merang, plastik wrap, dan lembar plastik. Benih kedelai varietas Anjasmoro yang digunakan adalah benih yang dipanen pada bulan November 2015 dan diperoleh dari produsen benih UPTD BPPTPH Unit Gading, Wonosari, Daerah Istimewa Yogyakarta. Alat-alat yang digunakan adalah kemasan hermetik, jeriken plastik, karung plastik, kantong plastik, alat perekat (sealer), oven suhu konstan, desikator, silica gel, dan mortar. Alat penunjang yang digunakan meliputi timbangan, cawan krusibel, gegep, sarung tangan, dan amplop. Rancangan percobaan yang digunakan adalah rancangan acak lengkap (Completely Randomize Design). Faktor perlakuan yang digunakan meliputi jenis kemasan (P) yang terdiri atas tiga taraf yaitu kemasan hermetik (P1), jeriken plastik (P2), dan karung beralas plastik (P3). Tiap perlakuan diulang tiga kali sehingga terdapat 9 satuan percobaan.

Pelaksanaan kegiatan penelitian terdiri dari beberapa kegiatan yaitu pengujian viabilitas benih awal, pengemasan benih, penyimpanan benih dan pengujian mutu benih. Pengujian viabilitas benih awal dilakukan sebelum proses penyimpanan yang bertujuan untuk mengetahui mutu fisik dan fisiologis benih sebelum disimpan. Peubah yang diamati dalam pengujian viabilitas awal meliputi kadar air, daya berkecambah benih, kecepatan tumbuh benih, indeks vigor benih, keserempakan tumbuh benih, dan bobot kering kecambah normal. Benih yang telah diuji kemudian dikemas ke dalam tiga kemasan yaitu kemasan hermetik, jeriken plastik dan karung beralas plastik.

Benih yang sudah dikemas kemudian disimpan di gudang penyimpanan dengan suhu rata-rata gudang $\pm 29^{\circ} \mathrm{C}$ dan kelembaban udara rata-rata 73\% selama 6 bulan. Pengujian benih dilakukan setiap bulan untuk mengetahui mutu fisik dan fisiologis benih selama penyimpanan. Peubah yang diamati meliputi kadar air (KA), daya berkecambah (DB), kecepatan tumbuh $\left(\mathrm{K}_{\mathrm{CT}}\right)$, indeks vigor (IV), keserempakan tumbuh (KST), dan bobot kering kecambah normal (BKKN). Data yang diperoleh dianalisis ragam (Uji F) untuk mengetahui ada tidaknya pengaruh dari perlakuan jenis kemasan terhadap peubah yang diamati. Hasil uji $\mathrm{F}$ yang menunjukkan pengaruh nyata dilakukan uji lanjut dengan Duncan Multiple Range Test (DMRT) pada taraf 5\%. Pengolahan data dilakukan dengan menggunakan software Ms. Exel dan SAS 9.0.

\section{HASIL DAN PEMBAHASAN}

\section{Viabilitas dan Vigor Awal Benih Kedelai}

Pengujian awal benih kedelai dilakukan sebelum penyimpanan yang meliputi pengujian kadar air, viabilitas dan vigor benih. Hasil pengujian rata-rata kadar air awal benih kedelai sebelum penyimpanan sebesar $7.75 \%$ dengan ratarata daya berkecambah benih sebesar $92 \%$ (Tabel 1). Kadar air dan daya berkecambah yang diperoleh masih sesuai standar sehingga dapat dilakukan penyimpanan.

Tabel 1. Rekapitulasi data pengujian kadar air, viabilitas dan vigor benih kedelai sebelum penyimpanan

\begin{tabular}{ccccccc}
\hline Ulangan & KA $(\%)$ & DB $(\%)$ & IV $(\%)$ & $\mathrm{K}_{\mathrm{CT}}(\%)$ & $\mathrm{K}_{\mathrm{ST}}(\%)$ & $\mathrm{BKKN}(\mathrm{g})$ \\
\hline 1 & 7.78 & 96 & 94 & 30.63 & 92 & 0.43 \\
2 & 7.86 & 88 & 88 & 27.25 & 88 & 0.51 \\
3 & 7.60 & 92 & 84 & 27.13 & 80 & 0.49 \\
\hline Rata-rata & 7.75 & 92 & 88.67 & 28.34 & 86.67 & 0.48 \\
\hline
\end{tabular}

Keterangan: KA: kadar air, DB: daya berkecambah, IV: indeks vigor, KCT: kecepatan tumbuh, KST: keserempakan tumbuh, BKKN: bobot kering kecambah normal 


\section{Pengaruh Jenis Kemasan terhadap Kadar Air Benih Kedelai}

Standar kandungan kadar air (KA) maksimum benih kedelai menurut Dirjen Tanaman Pangan (2009) adalah 11\%. KA awal rata-rata benih kedelai sebelum disimpan sebesar $7.75 \%$ (Tabel 1). Secara umum kadar air cenderung meningkat tiap bulannya selama penyimpanan, namun peningkatan tersebut masih di bawah standar yang telah ditetapkan. Hasil pengamatan KA pada Tabel 2 menunjukkan bahwa pada bulan pertama hingga bulan ke-4 perlakuan jenis kemasan tidak memberikan pengaruh yang nyata terhadap KA benih kedelai. Kemasan jeriken plastik mampu mempertahankan KA tetap rendah dibandingkan kemasan lainnya pada bulan ke-5 sebesar $8.51 \%$ dan bulan ke-6 sebesar $8.59 \%$. Hasil tersebut menunjukkan bahwa kemasan jeriken plastik lebih kedap udara sehingga KA benih selama penyimpanan tetap terjaga dan mampu melindungi benih dari pengaruh kelembaban udara di luar kemasan.

Pola perubahan KA rata-rata benih kedelai ketiga pelakuan pada tiap bulannya disajikan pada Gambar 1. Kadar air benih kedelai mengalami kenaikan pada bulan pertama $(8.78 \%)$, bulan ke-3 (8.86\%) dan bulan ke-5 (9.00\%). Peningkatan tersebut masih dibawah standar KA benih kedelai untuk disimpan. Sedangkan pada bulan ke-2 dan bulan ke-4 KA benih mengalami penurunan yaitu $8.41 \%$ dan $8.06 \%$. Kadar air benih mengalami fluktuasi disebabkan oleh beberapa faktor yaitu kualitas dan ketebalan jenis kemasan yang masih memungkinkan terjadi masuknya uap air ke dalam kemasan sehingga terjadi peningkatan kadar air benih.

Peningkatan kadar air pada kemasan porous dapat terjadi karena kondisi lingkungan yang tidak terkontrol dan permeabilitas kemasan yang rendah. Peningkatan kadar air pada kemasan kedap selama periode penyimpanan dapat disebabkan benih yang disimpan selama enam bulan tetap melakukan aktivitas metabolisme yaitu respirasi meskipun dikemas dalam kemasan kedap. Respirasi benih menghasilkan gas karbon dioksida dan uap air. Gas karbon dioksida dan uap air dalam kemasan porous dapat keluar masuk kemasan sedangkan dalam kemasan kedap gas tersebut tidak dapat keluar kemasan dan terus berada dalam kemasan sehingga dapat meningkatkan kadar air benih (Febriyanti, 2013).

Tabel 2. Pengaruh jenis kemasan terhadap KA benih kedelai selama penyimpanan

\begin{tabular}{|c|c|c|c|c|c|c|c|}
\hline \multirow{2}{*}{ Perlakuan } & \multicolumn{7}{|c|}{ Lama penyimpanan (BSS) } \\
\hline & 0 & 1 & 2 & 3 & 4 & 5 & 6 \\
\hline & & & & $\ldots(\%)$. & & & \\
\hline $\mathrm{P} 1$ & 7.78 & 8.71 & 8.32 & 8.08 & 8.21 & $9.01 b$ & $8.97 \mathrm{a}$ \\
\hline $\mathrm{P} 2$ & 7.86 & 8.83 & 8.35 & 8.27 & 7.73 & $8.51 \mathrm{c}$ & $8.59 b$ \\
\hline $\mathrm{P} 3$ & 7.60 & 8.81 & 8.55 & 10.24 & 8.24 & $9.49 \mathrm{a}$ & $9.28 \mathrm{a}$ \\
\hline Uji F & - & $0.89^{\mathrm{tn}}$ & $0.22^{\mathrm{tn}}$ & $0.16^{\mathrm{tn}}$ & $0.14^{\mathrm{tn}}$ & $0.00 * *$ & $0.01 * *$ \\
\hline KK & - & 3.74 & 1.83 & 14.83 & 3.72 & 1.96 & 1.83 \\
\hline
\end{tabular}

Keterangan: Angka yang diikuti huruf yang berbeda pada kolom yang sama menunjukkan berbeda nyata pada uji DMRT taraf 5\%, tn: tidak berpengaruh nyata pada uji F 95\%, **: berpengaruh nyata pada uji F 1\%, P1: plastik hermetik, P2: jeriken plastik, P3: karung berlapis plastik, BSS: bulan setelah simpan

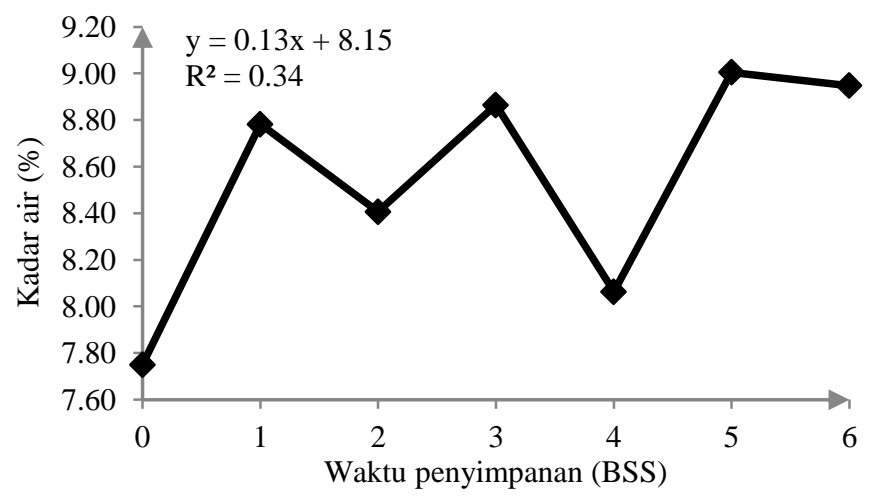

Gambar 1. Kadar air benih kedelai pada penyimpanan selama 6 bulan

Faktor penyebab KA mengalami fluktuasi lainnya adalah karena suhu dan RH pada bulan-bulan tersebut meningkat dari bulan sebelumnya dan menurun pada bulan berikutnya (Tabel 3). Febriyanti (2013) menyatakan bahwa peningkatan suhu ruang dapat meningkatkan 
aktivitas respirasi pada benih. Tingginya aktivitas respirasi dapat meningkatkan kadar air benih. Justice dan Bass (2002) menyatakan bahwa kadar air benih dipengaruhi oleh kelembaban nisbi ruang simpan. Kenaikan KA tersebut merupakan salah satu penyebab turunnya viabilitas benih. Menurut Harrington (1972) setiap peningkatan kadar air sebesar 1\% (pada kisaran 5-14\%) akan menurunkan daya simpan benih setengahnya.

Tabel 3. Rekapitulasi hasil pengamatan suhu dan RH selama penyimpanan

\begin{tabular}{|c|c|c|c|c|c|c|c|c|c|c|c|c|}
\hline \multirow{3}{*}{ Peubah } & \multicolumn{12}{|c|}{ Waktu Penyimpanan (bulan ke-) } \\
\hline & \multicolumn{2}{|c|}{1} & \multicolumn{2}{|c|}{2} & \multicolumn{2}{|c|}{3} & \multicolumn{2}{|c|}{4} & \multicolumn{2}{|c|}{5} & \multicolumn{2}{|c|}{6} \\
\hline & $\begin{array}{c}\text { Suhu } \\
\left({ }^{\circ} \mathrm{C}\right)\end{array}$ & $\begin{array}{l}\mathrm{RH} \\
(\%)\end{array}$ & $\begin{array}{l}\text { Suhu } \\
\left({ }^{\circ} \mathrm{C}\right)\end{array}$ & $\begin{array}{l}\mathrm{RH} \\
(\%)\end{array}$ & $\begin{array}{c}\text { Suhu } \\
\left({ }^{\circ} \mathrm{C}\right)\end{array}$ & $\begin{array}{l}\mathrm{RH} \\
(\%)\end{array}$ & $\begin{array}{c}\text { Suhu } \\
\left({ }^{\circ} \mathrm{C}\right)\end{array}$ & $\begin{array}{l}\text { RH } \\
(\%)\end{array}$ & $\begin{array}{c}\text { Suhu } \\
\left({ }^{\circ} \mathrm{C}\right)\end{array}$ & $\begin{array}{l}\mathrm{RH} \\
(\%)\end{array}$ & $\begin{array}{l}\text { Suhu } \\
\left({ }^{\circ} \mathrm{C}\right)\end{array}$ & $\begin{array}{l}\mathrm{RH} \\
(\%)\end{array}$ \\
\hline Mininum & 27.8 & 69.0 & 27.2 & 67.0 & 28.2 & 62.0 & 28.2 & 60.0 & 27.9 & 66.0 & 27.4 & 52.0 \\
\hline Maksimum & 29.2 & 86.0 & 30.5 & 88.0 & 30.4 & 83.0 & 30.5 & 80.0 & 30.1 & 78.0 & 29.4 & 80.0 \\
\hline Rata-Rata & 28.2 & 77.9 & 29.0 & 77.8 & 29.4 & 73.0 & 29.6 & 72.3 & 28.9 & 70.8 & 28.4 & 68.4 \\
\hline
\end{tabular}

\section{Pengaruh Jenis Kemasan terhadap Viabilitas dan Vigor Benih Kedelai}

Daya Berkecambah (DB). Perlakuan jenis kemasan tidak memberikan pengaruh yang nyata terhadap persentase DB benih kedelai selama penyimpanan. Persentase rata-rata DB awal benih kedelai sebelum disimpan adalah $92 \%$ (Tabel 1). Persentase DB tersebut tergolong lebih tinggi dari standar minimum daya berkecambah benih yaitu $80 \%$. Hasil pengamatan pada Tabel 4 menunjukan bahwa perlakuan jenis kemasan pada bulan pertama memiliki daya berkecambah diatas $80 \%$ untuk semua perlakuan. Pada bulan ke-2 hanya kemasan jeriken plastik yang dapat mempertahankan daya berkecambah benih kedelai sebesar $80 \%$. Sedangkan pada bulan ke-3 hingga ke-6 daya berkecambah benih terus menurun hingga mencapai rata-rata $45 \%$ dari seluruh perlakuan.

Tabel 4. Pengaruh jenis kemasan terhadap DB benih kedelai selama penyimpanan

\begin{tabular}{|c|c|c|c|c|c|c|c|}
\hline \multirow{2}{*}{ Perlakuan } & \multicolumn{7}{|c|}{ Lama penyimpanan (BSS) } \\
\hline & 0 & 1 & 2 & 3 & 4 & 5 & 6 \\
\hline P1 & 96 & 82.67 & 69.33 & $\begin{array}{l}\ldots(\%) \\
66.67\end{array}$ & 57.33 & 66.67 & 45.33 \\
\hline P2 & 88 & 89.33 & 80.00 & 66.67 & 54.67 & 50.67 & 42.67 \\
\hline P3 & 92 & 82.67 & 76.00 & 57.33 & 54.67 & 42.67 & 46.67 \\
\hline Uji F & - & $0.48^{\mathrm{tn}}$ & $0.28^{\text {tn }}$ & $0.49^{\text {tn }}$ & $0.96^{\mathrm{tn}}$ & $0.09^{\text {tn }}$ & $0.50^{\mathrm{tn}}$ \\
\hline KK & - & 8.60 & 9.88 & 16.25 & 23.14 & 20.31 & 8.91 \\
\hline
\end{tabular}

Keterangan: tn: tidak berpengaruh nyata pada uji F 95\%, P1: plastik hermetik, P2: jeriken plastik, P3: karung berlapis plastik, BSS: bulan setelah simpan

Pola penurunan persentase DB rata-rata benih kedelai ketiga pelakuan pada tiap bulannya disajikan pada Gambar 2. Secara umum persentase DB rata-rata benih kedelai ketiga perlakuan mengalami penurunan tiap bulannya. Penurunan tersebut sebagaimana telah dijelaskan sebelumnya bahwa peningkatan kadar air merupakan penyebab penurunan viabilitas benih. Peningkatan kadar air ini yang menyebabkan peningkatan aktivitas metabolisme benih, sehingga cadangan makanan untuk proses perkecambahan semakin berkurang. Menurut Dewi (2002) kondisi lingkungan di sekitar tempat penyimpanan mempengaruhi tingkat respirasi benih, sehingga suhu di sekeliling benih meningkat. Pengaruh kadar air, suhu dan kelembaban pada ruang penyimpanan merupakan penyebab utama kemunduran benih. Proses perombakan cadangan makanan berjalan lebih cepat pada saat benih mengalami kemunduran. Harrington (1973) menyatakan bahwa suhu dan kadar air tinggi merupakan faktor penyebab menurunnya daya berkecambah dan vigor.

Chai et al. (2002) menyatakan bahwa perkecambahan benih kedelai akan menurun dari perkecambahan awal yaitu diatas $90 \%$ menjadi $0 \%$ tergantung spesies dan kadar air selama penyimpanan. Yaya et al. (2003) menyatakan bahwa benih kedelai yang disimpan dengan kadar air $6 \%$ dan $8 \%$ selama 4 bulan pada suhu $15{ }^{\circ} \mathrm{C}$ memiliki persentase perkecambahan diatas $70 \%$. Sedangkan suhu rata-rata selama penelitian mencapai $28.9{ }^{\circ} \mathrm{C}$ (Tabel 3). Hal inilah yang menyebabkan penurunan persentase DB pada tiap bulannya hingga mencapai $45 \%$ pada akhir periode penyimpanan. 


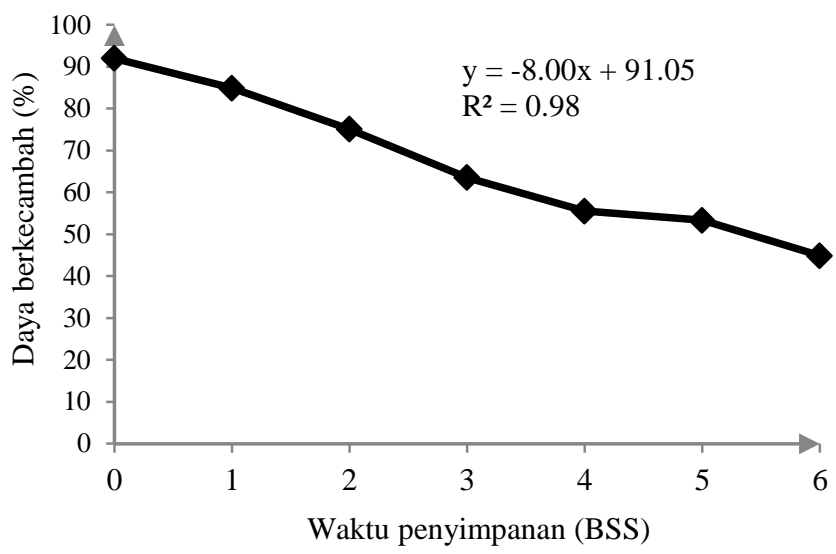

Gambar 2. Daya berkecambah benih kedelai pada penyimpanan selama 6 bulan

Indeks Vigor (IV). Indeks vigor awal benih kedelai sebelum disimpan adalah $88.67 \%$ (Tabel 1). Kemudian mengalami penurunan tiap bulannya selama penyimpanan. Hasil pengamatan pengaruh jenis kemasan terhadap IV benih kedelai (Tabel 5) menunjukan bahwa perlakuan jenis kemasan berpengaruh nyata secara statistik pada bulan pertama. Perlakuan jenis kemasan pada bulan ke-2 berpengaruh sangat nyata secara statistik terhadap IV benih kedelai. Kemasan jeriken plastik merupakan kemasan terbaik dengan nilai IV tertinggi dibandingkan dengan kemasan lainnya pada bulan pertama dan ke-2. Indeks vigor benih kedelai mengalami penurunan pada bulan berikutnya yaitu pada bulan ke-3 hingga ke-6.
Indeks vigor tiap perlakuan mengalami peningkatan pada bulan ke-2 sebesar $54.67 \%$ dan bulan ke-4 sebesar $18.67 \%$. Nilai IV terus menurun pada bulan berikutnya hingga akhir periode penyimpanan. Pola penurunan persentase IV rata-rata benih kedelai ketiga pelakuan pada tiap bulannya disajikan pada Gambar 3. Nilai persentase IV yang tinggi menunjukan bahwa benih memiliki kemampuan berkecambah lebih cepat dan serempak serta mampu menghadapi kondisi sub-optimum. Indeks vigor yang terus menurun tiap bulannya menunjukan bahwa vigor kekuatan tumbuh benih kedelai semakin rendah atau kemunduran benih. Menurut Kartasapoetra (2003) kemunduran benih mengakibatkan rendahnya kekuatan kecambah dan buruknya pertanaman serta hasil.

Tabel 5. Pengaruh jenis kemasan terhadap IV benih kedelai selama penyimpanan

\begin{tabular}{lccccccc}
\hline \multirow{2}{*}{ Perlakuan } & \multicolumn{7}{c}{ Lama penyimpanan (BSS) } \\
\cline { 2 - 8 } & 0 & 1 & 2 & 3 & 4 & 5 & 6 \\
\hline & & & $\ldots \ldots \ldots \ldots \ldots \ldots .(\%) \ldots \ldots \ldots \ldots \ldots \ldots \ldots \ldots \ldots \ldots \ldots$ & 12.00 & 0.00 \\
P1 & 94 & $28.00 \mathrm{~b}$ & $53.33 \mathrm{~b}$ & 22.67 & 16.00 & 5.33 & 2.67 \\
P3 & 88 & $49.33 \mathrm{a}$ & $69.33 \mathrm{a}$ & 17.33 & 20.00 & 2.67 & 1.33 \\
\hline Uji F & 84 & $22.67 \mathrm{~b}$ & $41.33 \mathrm{~b}$ & 13.33 & 20.00 & 2.67 \\
KK & - & $0.04^{*}$ & $0.01^{* *}$ & $0.39^{\text {tn }}$ & $0.63^{\text {th }}$ & $0.14^{\text {tn }}$ & $0.30^{\text {tn }}$ \\
\hline
\end{tabular}

Keterangan: Angka yang diikuti huruf yang berbeda pada kolom yang sama menunjukkan berbeda nyata pada uji DMRT taraf 5\%, tn: tidak berpengaruh nyata pada uji F 95\%, *: berpengaruh nyata pada uji F 5\%, **: berpengaruh nyata pada uji $\mathrm{F} 1 \%$, P1: plastik hermetik, P2: jeriken plastik, P3: karung berlapis plastik, BSS: bulan setelah simpan

Peningkatan indeks vigor pada bulan ke-2 dan ke-4 disebabkan oleh penurunan kadar air pada bulan tersebut. Hasil pengamatan KA menunjukan penurunan KA pada bulan ke-2 dan ke-4 (Tabel 2). Peningkatan kadar air menyebabkan penurunan persentase IV, sebaliknya pada kadar air yang rendah benih dapat mempetahankan viabilitas dan vigornya. Menurut Harrington (1973) faktor penyebab penurunan vigor dan daya berkecambah adalah suhu dan kadar air tinggi. Justice dan Bass (2002) menyatakan bahwa kadar air benih dipengaruhi oleh kelembaban nisbi ruang simpan. Harrington (1972) menjelaskan bahwa setiap peningkatan kadar air sebesar 1\% (pada kisaran 5-14\%) akan menurunkan daya simpan benih setengahnya. Menurut Dewi (2002) vigor benih dapat dipertahankan bila benih disimpan dalam kondisi yang sesuai. Suhu yang rendah dengan batas waktu tertentu mengakibatkan aktivitas 
metabolisme benih rendah dan penggunaan energi menjadi lebih kecil, sehingga benih dapat

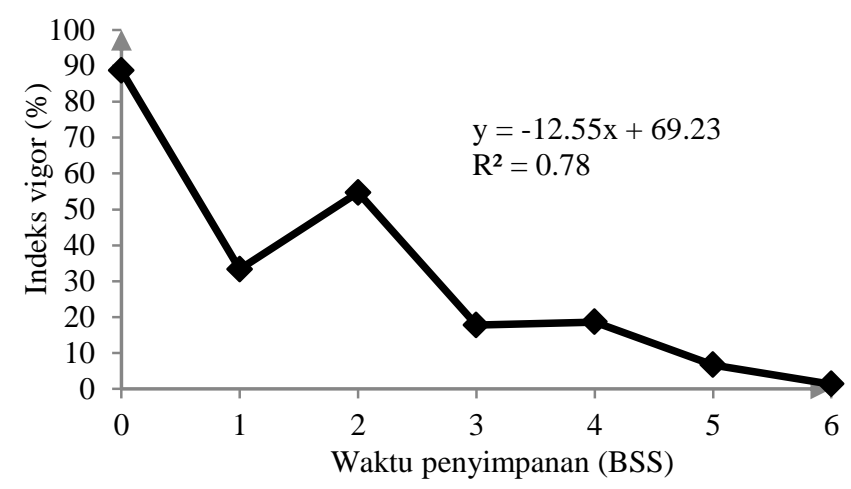

Gambar 3. Indeks vigor benih kedelai pada penyimpanan selama 6 bulan

Kecepatan Tumbuh $\left(\mathrm{K}_{\mathrm{CT}}\right)$. Perlakuan jenis kemasan tidak memberikan pengaruh yang nyata terhadap $\mathrm{K}_{\mathrm{CT}}$ benih kedelai selama penyimpanan (Tabel 6). Hasil pengujian $\mathrm{K}_{\mathrm{CT}}$ awal benih kedelai sebelum disimpan adalah $28.34 \% \mathrm{KN}$ etmal $^{-1}$ (Tabel 1). Perlakuan kemasan hermetik pada bulan pertama menunjukan $\mathrm{K}_{\mathrm{CT}}$ terbaik dibandingkan kemasan lainnya yaitu $25.53 \% \mathrm{KN}$ etmal $^{-1}$. Hasil tersebut tidak berbeda nyata secara statistik untuk semua kemasan. Kemudian mengalami penurunan pada bulan ke-2 menjadi $23.13 \% \mathrm{KN}$ etmal $^{-1}$ dan bulan ke-3 sebesar $14.00 \% \mathrm{KN}_{\text {etmal }}{ }^{-1}$. Bulan ke-4, $\mathrm{K}_{\mathrm{CT}}$ kembali meningkat menjadi $19.91 \% \mathrm{KN}$ etmal ${ }^{-1}$ dan terus menurun hingga akhir periode penyimpanan. Kemasan jeriken plastik menunjukan hasil terbaik pada bulan ke-2 $\left(28.56 \% \quad \mathrm{KN} \quad \mathrm{etmal}^{-1}\right)$ dibandingkan dengan kemasan lainnya. Kemudian mengalami penurunan pada bulan berikutnya selama penyimpanan. Hasil tersebut juga tidak berbeda nyata secara statistik dengan kemasan lainnya.
Pola penurunan $\mathrm{K}_{\mathrm{CT}}$ rata-rata benih kedelai ketiga pelakuan pada tiap bulannya disajikan pada Gambar 4. Tolok ukur $\mathrm{K}_{\mathrm{CT}}$ mengindikasikan vigor kekuatan tumbuh benih yang cepat tumbuh lebih mampu menghadapi kondisi lapang yang sub-optimum (Sadjad, 1993). Benih vigor menunjukkan nilai $\mathrm{K}_{\mathrm{CT}}$ yang tinggi, karena benih tersebut berkecambah lebih cepat pada waktu yang relatif singkat. Benih yang kurang vigor akan berkecambah normal untuk jangka waktu yang lebih lama (Sadjad et al., 1999). Nilai rata-rata $K_{C T}$ untuk semua perlakuan mengalami peningkatan pada bulan ke-2 menjadi $25.76 \% \mathrm{KN}_{\mathrm{N}}$ etmal $^{-1}$ dan bulan ke-4 sebesar $17.38 \% \quad \mathrm{KN}$ etmal $^{-1}$. Peningkatan nilai $\mathrm{K}_{\mathrm{CT}}$ tersebut menunjukan bahwa benih kedelai mampu mempertahankan vigor kekuatan tumbuh pada bulan ke-2 dan ke-4. Kemampuan vigor kekuatan tumbuh tersebut terus mengalami penurunan yang disebabkan oleh penurunan viabilitas benih.

Tabel 6. Pengaruh jenis kemasan terhadap $\mathrm{K}_{\mathrm{CT}}$ benih kedelai selama penyimpanan

\begin{tabular}{|c|c|c|c|c|c|c|c|}
\hline \multirow{2}{*}{ Perlakuan } & \multicolumn{7}{|c|}{ Lama penyimpanan (BSS) } \\
\hline & 0 & 1 & 2 & 3 & 4 & 5 & 6 \\
\hline & & & ......... ( & etmal $^{-1}$ ) & & & \\
\hline P1 & 30.63 & 25.53 & 23.13 & 14.00 & 19.91 & 13.36 & 13.06 \\
\hline P2 & 27.25 & 24.13 & 28.56 & 16.62 & 16.69 & 13.24 & 12.80 \\
\hline P3 & 27.13 & 22.84 & 25.58 & 20.09 & 15.53 & 12.93 & 11.67 \\
\hline Uji F & - & $0.50^{\mathrm{tn}}$ & $0.06^{\mathrm{tn}}$ & $0.11^{\mathrm{tn}}$ & $0.08^{\mathrm{tn}}$ & $0.98^{\mathrm{tn}}$ & $0.74^{\mathrm{tn}}$ \\
\hline KK & - & 10.79 & 8.55 & 17.2 & 11.27 & 18.82 & 18.42 \\
\hline
\end{tabular}

Keterangan: KN: kecambah normal, tn: tidak berpengaruh nyata pada uji F 95\%, P1: plastik hermetik, P2: jeriken plastik, P3: karung berlapis plastik, BSS: bulan setelah simpan 


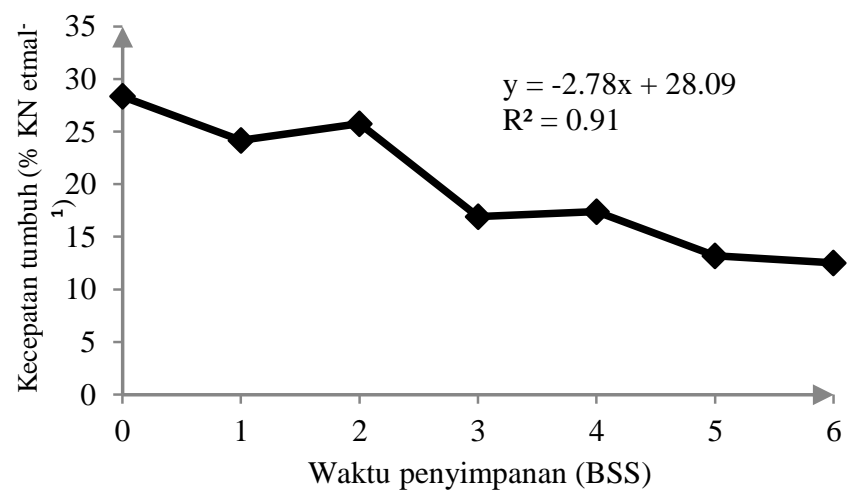

Gambar 4. Kecepatan tumbuh benih kedelai pada penyimpanan selama 6 bulan

Keserempakan Tumbuh $\quad\left(\mathrm{K}_{\mathrm{ST}}\right)$. Keserempakan tumbuh adalah tumbuhnya benih secara homogen, serempak berkecambah dan mewujudkan kinerja kecambah yang seragam (Sadjad et al., 1999). Nilai $\mathrm{K}_{\mathrm{ST}}$ mengindikasikan vigor suatu lot benih. Lot benih yang kurang vigor akan tumbuh bervariasi sehingga menyulitkan masa panen. Benih yang memiliki vigor yang tinggi akan lebih serempak berkecambah, karena memiliki cadangan makanan yang tinggi, sehingga dapat membantu untuk berkecambah secara serempak di lingkungan yang optimum maupun yang sub-optimum (Febriyanti, 2013). Perlakuan jenis kemasan tidak memberikan pengaruh yang nyata terhadap $\mathrm{K}_{\mathrm{ST}}$ benih kedelai selama penyimpanan (Tabel 7). Persentase ratarata keserempakan tumbuh awal benih kedelai sebelum disimpan adalah $86.67 \%$ (Tabel 1). Pada bulan pertama terlihat bahwa kemasan jeriken plsatik memberikan hasil terbaik dibandingkan dengan kemasan lainnya yaitu $72.00 \%$. Namun hasil tersebut tidak berbeda nyata dengan kemasan lainnya. Persentase $\mathrm{K}_{\mathrm{ST}}$ pada tiap bulannya terus mengalami penurunan hingga bulan ke- 6 .

Tabel 7. Pengaruh jenis kemasan terhadap $\mathrm{K}_{\mathrm{ST}}$ benih kedelai selama penyimpanan

\begin{tabular}{|c|c|c|c|c|c|c|c|}
\hline \multirow{2}{*}{ Perlakuan } & \multicolumn{7}{|c|}{ Lama penyimpanan (BSS) } \\
\hline & 0 & 1 & 2 & 3 & 4 & 5 & 6 \\
\hline & & & & $\%) \ldots \ldots$ & & & \\
\hline P1 & 92 & 66.67 & 68.00 & 62.67 & 50.67 & 37.33 & 28.00 \\
\hline $\mathrm{P} 2$ & 88 & 72.00 & 74.67 & 53.33 & 50.67 & 46.67 & 36.00 \\
\hline P3 & 80 & 65.33 & 76.00 & 58.67 & 48.00 & 36.00 & 24.00 \\
\hline Uji F & - & $0.66^{\mathrm{tn}}$ & $0.17^{\mathrm{tn}}$ & $0.72^{\text {th }}$ & $0.91^{\mathrm{tn}}$ & $0.27^{\mathrm{tn}}$ & $0.07^{\text {tn }}$ \\
\hline KK & - & 13.44 & 6.60 & 23.47 & 17.15 & 19.72 & 17.60 \\
\hline
\end{tabular}

Keterangan: tn: tidak berpengaruh nyata pada uji F 95\%, P1: plastik hermetik, P2: jeriken plastik, P3: karung berlapis plastik, BSS: bulan setelah simpan

Keserempakan tumbuh merupakan salah satu tolok ukur untuk parameter vigor kekuatan tumbuh yang diperoleh dari persentase kecambah normal kuat pada saat pengujian. Nilai $\mathrm{K}_{\mathrm{ST}}$ juga dapat mengindikasikan vigor daya simpan benih (Sadjad, 1993). Pola penurunan persentase $\mathrm{K}_{\mathrm{ST}}$ rata-rata benih kedelai ketiga pelakuan pada tiap bulannya disajikan pada Gambar 5. Hasil pengamatan rata-rata $\mathrm{K}_{\mathrm{ST}}$ untuk seluruh perlakuan menunjukan bahwa nilai $\mathrm{K}_{\mathrm{ST}}$ meningkat pada bulan ke-2 menjadi $72.89 \%$ dan kemudian terus menurun pada bulan berikutnya hingga bulan ke6. Nilai $\mathrm{K}_{\mathrm{ST}}$ yang tinggi menunjukan bahwa daya simpan benih yang tinggi pula. Daya simpan benih kedelai dapat dipertahankan tetap tinggi hingga bulan ke-2 dan kemudian terus menurun sampai akhir periode penyimpanan. 


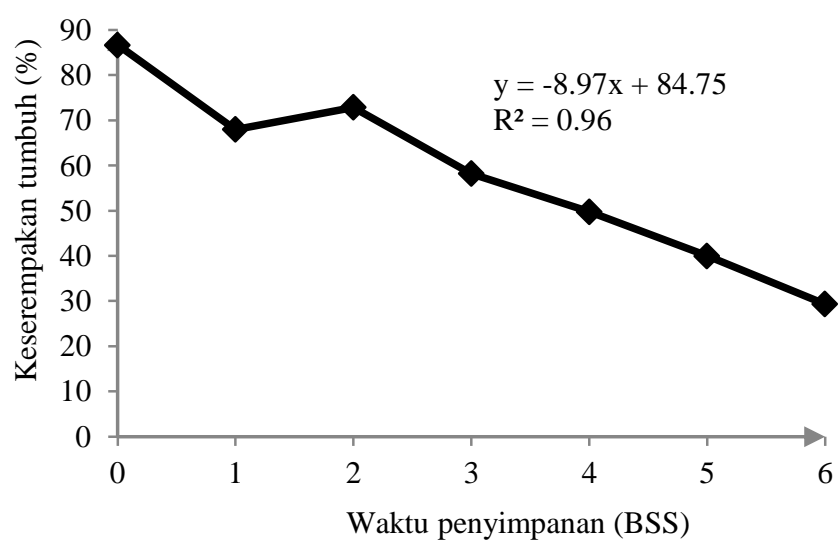

Gambar 5. Keserempakan tumbuh benih kedelai pada penyimpanan selama 6 bulan

\begin{abstract}
Bobot Kering Kecambah Normal (BKKN). Bobot kering kecambah normal menggambarkan banyaknya cadangan makanan yang tersedia dalam kotiledon, sehingga bila benih disimpan pada suhu dan RH yang relatif rendah mengakibatkan cadangan makanan dalam benih tidak akan mengalami perubahan jumlah yang besar. Kondisi lingkungan simpan yang demikian, suatu saat apabila benih dikecambahkan mampu tumbuh dan berkembang dengan baik (Sadjad, 1980). Perlakuan jenis kemasan tidak memberikan pengaruh yang nyata terhadap BKKN benih kedelai selama penyimpanan. Hasil rata-rata BKKN awal benih kedelai sebelum disimpan adalah $0.48 \mathrm{~g}$ (Tabel 1). Nilai BKKN yang tinggi dapat diartikan bahwa kecambah menyerap lebih banyak cadangan makanan di dalam kotiledon dibandingkan dengan nilai BKKN yang rendah selama proses perkecambahan. Prawiranata et al. (1992) menjelaskan benih yang memiliki viabilitas tinggi
\end{abstract}

mampu menghasilkan berat kering bibit yang tinggi pada kondisi optimum maupun suboptimum. Peningkatan berat kering bibit merupakan akumulasi pemindahan hasil-hasil perombakan cadangan makanan (metabolit) dari endosperm ke embrio.

Hasil penelitian pada Tabel 8 menunjukan bahwa kemasan hermetik memberikan hasil BKKN terbaik pada bulan ke-2 (0.50 g) dan ke-6 $(0.54 \mathrm{~g})$. Kemasan jeriken plastik menunjukan hasil BKKN terbaik pada bulan pertama $(0.52 \mathrm{~g})$ dan ke-4 (0.55 g). Kemasan karung beralas plastik memberikan hasil BKKN terbaik pada bulan ke-3 $(0.51 \mathrm{~g})$ dan ke-5 (0.57 g) selama periode penyimpanan. Namun secara statistik hasil tersebut menunjukan tidak adanya perbedaan yang nyata untuk semua perlakuan. Hal tersebut membuktikan bahwa perlakuan jenis kemasan tidak memberikan pengaruh yang nyata terhadap hasil BKKN benih kedelai selama penyimpanan.

Tabel 8. Pengaruh jenis kemasan terhadap BKKN benih kedelai selama penyimpanan

\begin{tabular}{|c|c|c|c|c|c|c|c|}
\hline \multirow{2}{*}{ Perlakuan } & \multicolumn{7}{|c|}{ Lama penyimpanan (BSS) } \\
\hline & 0 & 1 & 2 & 3 & 4 & 5 & 6 \\
\hline & & & & $(g) \ldots$ & & & \\
\hline $\mathrm{P} 1$ & 0.43 & 0.50 & 0.50 & 0.47 & 0.53 & 0.49 & 0.54 \\
\hline $\mathrm{P} 2$ & 0.51 & 0.52 & 0.49 & 0.50 & 0.55 & 0.48 & 0.53 \\
\hline P3 & 0.49 & 0.50 & 0.47 & 0.51 & 0.50 & 0.57 & 0.52 \\
\hline Uji F & - & $0.88^{\mathrm{tn}}$ & $0.72^{\mathrm{tn}}$ & $0.65^{\text {tn }}$ & $0.45^{\mathrm{tn}}$ & $0.06^{\mathrm{tn}}$ & $0.81^{\mathrm{tn}}$ \\
\hline KK & - & 9.69 & 9.57 & 10.31 & 8.67 & 7.17 & 6.23 \\
\hline
\end{tabular}

Keterangan: tn: tidak berpengaruh nyata pada uji F 95\%, P1: plastik hermetik, P2: jeriken plastik, P3: karung berlapis plastik, BSS: bulan setelah simpan

Pola hasil rata-rata BKKN benih kedelai ketiga pelakuan pada tiap bulannya disajikan pada Gambar 6. Nilai rata-rata BKKN semua pelakuan meningkat pada bulan pertama yaitu $0.50 \mathrm{~g}$, bulan ke-4 sebesar $0.53 \mathrm{~g}$ dan bulan ke-6 sebesar $0.53 \mathrm{~g}$. Kemudian BKKN menurun pada bulan ke-2 (0.49 g), ke-3 (0.49 g) dan ke-5 (0.51 g). Penurunan hasil BKKN diduga disebabkan oleh peningkatan suhu saat penyimpanan (Tabel 3). Justice dan Bass (1994) menyatakan bahwa viabilitas dan vigor benih menurun sejalan dengan meningkatnya suhu. Peningkatan suhu ruang simpan akan menyebabkan laju respirasi dan perombakan cadangan makanan berlangsung 
semakin cepat. Selama respirasi berlangsung terjadi penggunaan cadangan makanan berupa karbohidrat dalam bentuk gula dan pati akan diurai terlebih dahulu, kemudian dilanjutkan protein dan lemak. Pada kondisi lingkungan tidak menguntungkan, proses respirasi akan berlangsung secara terus menerus. Sadjad (1980) menjelaskan bahwa benih yang telah berespirasi aktif selama periode simpan akan kehabisan energi untuk tumbuh pada saat perkecambahan.

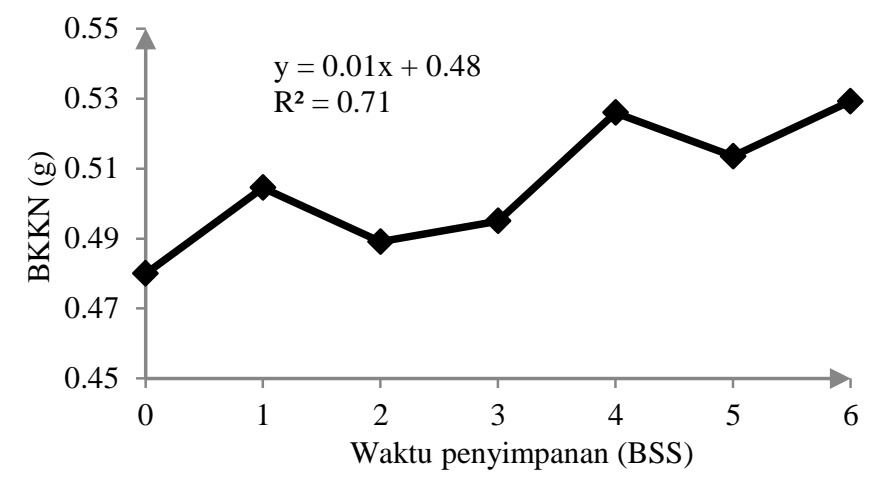

Gambar 6. Bobot kering kecambah normal benih kedelai pada penyimpanan selama 6 bulan

\section{KESIMPULAN}

Perlakuan jenis kemasan memberikan pengaruh yang sangat nyata terhadap kadar air benih kedelai pada bulan ke-5 dan ke-6. Kemasan jeriken plastik merupakan kemasan terbaik yang mempertahankan kadar air benih pada bulan ke-5 sebesar $8.51 \%$ dan bulan ke-6 sebesar $8.59 \%$. Perlakuan jenis kemasan juga berpengaruh sangat nyata terhadap indeks vigor benih kedelai pada bulan bulan ke-2 dan berpengaruh nyata pada bulan pertama. Indeks vigor terbaik yang diperoleh pada bulan ke-2 sebesar $69.33 \%$ dan bulan pertama sebesar $49.33 \%$ terdapat pada perlakuan kemasan jeriken plastik. Perlakuan jenis kemasan tidak memberikan pengaruh yang nyata terhadap variabel daya berkecambah, kecepatan tumbuh, keserempakan tumbuh dan bobot kering kecambah normal benih kedelai selama penyimpanan. Perlakuan jenis kemasan dapat mempertahankan viabilitas dan vigor benih kedelai hingga bulan ke-2 penyimpanan. Hasil tersebut menunjukan bahwa benih kedelai dapat disimpan selama empat bulan setelah panen.

\section{DAFTAR PUSTAKA}

[BPS] Badan Pusat Statistika. 2015. Data produksi kedelai tahun 2014. [internet]. [diunduh 2015 Okt 31]. Tersedia pada http://www.bps.go.id/.

Chai, J., Ma, R., Li, L., Du, L. 2001. Optimum moisture contents of seed agricultural physics, physiological and biochemical. Institut Hebey Academy of Agricultural and Forestry Sciences. Shijiazhuang. China.
Copeland, L.O., McDonald, M.B. 2001. Principles of seed science and technology. 4th edition. London (UK): Kluwer Academic Publishers.

Copeland, L.O. 1976. Principles of seed science and technology. Mineapolis, Minneasota. Burgess Publishing Co.

Dewi, M. 2002. Pengaruh kondisi ruang simpan dan jenis kemasan terhadap viabilitas benih kangkung darat (Ipomoea reptans Poir) pada beberapa periode simpan. [Skripsi]. Institut Pertanian Bogor. Bogor.

Dirjen Tanaman Pangan. 2009. Persyaratan dan tatacara sertifikasi benih bina tanaman pangan. [internet]. [diunduh 2016 Agust 08]. Tersedia pada http://perundangan.pertanian.go.id/.

Febriyanti, F. 2013. Viabilitas benih koro pedang putih (Canavalia ensiformis (L.) DC.) yang disimpan pada beberapa jenis kemasan dan periode simpan. [Skripsi]. Institut Pertanian Bogor. Bogor.

Harrington, J.F. 1972. Seed storage and longevity. Dalam: Kozlowski T.T, editor. Seed biology, Vol III. New York (US): Acad Press.

Harrington, J.F. 1973. Biochemical basis of seed longevity. Seed Science and Technology. (1):453 - 461 . 
Justice, O., Bass L.N. 2002. Prinsip dan praktek penyimpanan benih. Roesli R, penerjemah. Terjemahan dari: Principles and practices of seed storage. Jakarta(ID): PT Raja Grafindo Persada.

Kartasapoetra A.G. 2003. Teknologi benih (Pengolahan benih dan tuntunan praktikum). Jakarta(ID): Rineka Cipta.

Kartono. 2004. Teknik penyimpanan kedelai varietas wilis pada kadar air dan suhu penyimpanan yang berbeda. Bul. Tekper. 9(2): 79-82.

Owen, E.B. 1956. The storage of maintenance of viability. Bull 43. Commoewealth Agr. Bureaux farnham Royal, Buck, England.

Prawiranata, W., Harran, S., Tjondronegoro, P. 1992. Dasar-dasar fisiologi tumbuhan. Fakultas Matematika dan Ilmu Alam. Institut Pertanian Bogor. Bogor.

Purwanti, S. 2004. Kajian suhu ruang simpan terhadap kualitas benih kedelai hitam dan kedelai kuning. J. Ilmu Pertanian Indonesia. (11):22-31.
Sadjad, S. 1977. Penyimpanan benih tanaman pangan. Badan Latihan Pola Bertanam. LPDP-IRRI.

Sadjad, S. 1980. Panduan mutu benih tanaman kehutanan di Indonesia. Institut Pertanian Bogor. Bogor.

Sadjad, S. 1993. Dari benih kepada benih. Jakarta (ID) : Grasindo.

Sadjad S., Murniati E., dan Ilyas S. 1999. Parameter pengujian vigor benih dari komperatif ke simulatif. Jakarta(ID): Grasindo.

Tatipata, A., Yudono, P., Purwantoro, A., Mangoendidjojo, W. 2004. Kajian aspek fisiologi dan biokimia deteriorasi benih kedelai dalam penyimpanan. J. Ilmu Pertanian. 11(2): 76-87.

Yaya, Y., Vearasilp, S., Phosupongi, S., Tpoweezik E. 2003. Prediction of soybean seed viablity and quality in relation to seed moisture contents and storage temperature. Chiangmay University, Department of Agronomy. Thailand. 